\section{AIDS research}

\section{Is there really a virus?}

\section{Brussels}

MINUTE freckles on a photograph of human lymphocytes taken by two Brusselsbased medical researchers could, they claim, be images of a virus responsible for acquired immune deficiency syndrome (AIDS). The lymphoctyes were isolated from the blood of a Zairean patient under observation at the Brussels University St Pierre Hospital.

The findings of Dr Walter Feremans and Dr Nathan Clumeck of the Electron Microscope Department of Université Libre de Bruxelles (ULB) and four colleagues (Lancet ii, 52-53; 1983) were reprinted in Belgium's weekly La Revue de Medecin

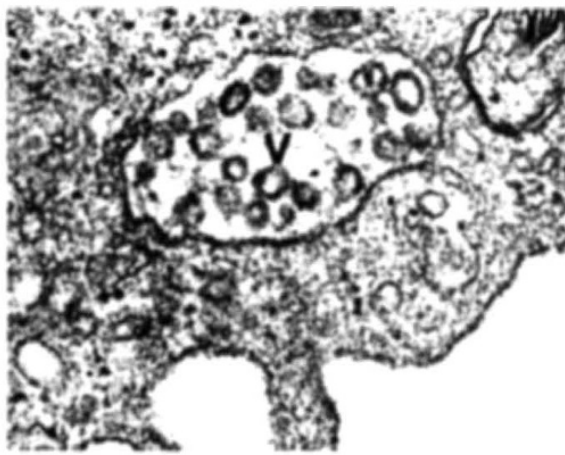

Virus-like inclusions $(V)$ in a lymphocyte (from Lancet $i i, 52 ; 1983)$.

and caught the eye of a Brussels reporter of the French news agency AFP. Her somewhat sensationalist article stirred up strong chauvinistic feelings in the Belgian press and started what Dr Feremans called "a highly undesirable tidal wave of often inaccurate reports",

In the Lancet letter the authors signal the existence of the small spots in lymphocytes of all seven AIDS victims being treated at the St Pierre Hospital. They go on to speculate that the specks could be a virus and could possibly have something to do with AIDS.

The researchers suspected the spots were a virus, but at that stage did not know whether they caused the illness or if the virus had made its way into the cells as a result of the deficiency in the patients' immune systems. "There were indications but we had to be cautious," Dr Feremans said. But research has progressed since the Lancet letter, and recent experiments seem to confirm a link between the virus and AIDS.

Understandably, Clumeck and Feremans, who are preparing another article for the Lancet, are reluctant to expand on the results of their experiments, but the few indications Feremans is willing to give are intriguing. First, there is increasing evidence that the grey spots on the picture are indeed a virus. "Markings and tests with colloidal gold point at a virus. The virus doesn't seem to be of the human T-cell leukaemia (HTLV) kind," said a cautious Feremans. But what could be a

Australia major breakthrough came up when the team performed blood tests on the wife of one of the seven AIDS patients at St Pierre Hospital. The tests suggest that the woman is suffering from AIDS at a very early, asymptomatic stage. And the electron micrographs again reveal the same grey spots. "We know that after the press campaign, the international scientific community had its heavy artillery in position to shoot us to pieces if our discovery proved to be wrong," said Feremans, "but this does give us hope."

The idea of examining the (black) woman's lymphocytes came up when the team found out the married couple had lost a newborn child only months after its birth in Africa. The child reportedly died of multiple infections. "We identified the woman as an AIDS patient. But the illness is in its earliest stage. The woman's natural defences are still functioning properly, and in any case would have been sufficient to eliminate or to keep out undesirable viruses,' Feremans said.

The next step will be to concentrate on isolating the virus. "The only thing we have done so far is photographing what might be the AIDS virus," he said. The Brussels branch of the Institut Pasteur which prepares the lymphocytes for the experiments is also attempting to isolate the virus.

The massive publicity surrounding Feremans' and Clumeck's experiments, and the chauvinism of the press have highlighted the sorry state of public medical research funding in Belgium. More than 40 cases of AIDS have been identified in the country and twelve deaths have been recorded so far, making Belgium one of Europe's hardest-hit countries. But no extra funds have been made available and coordination between the various Belgian institutes is restricted to the exchange of information because money is scarce.

Geert Linnebank

\title{
CSIRO in tangle with government
}

Canberra

MEMBERS of the executive of Australia's Commonwealth Science and Industrial Research Organization (CSIRO) are still smarting as a result of a recent directive from the government minister responsible for the organization. The directive, which was sent during pre-budget discussions with the CSIRO executive when the cut in the organization's 1983-84 budget was mooted (see Nature 15 September, p. 174), makes bland reading: "I, Barry Owen Jones. . . direct the executive of CSIRO to devote the same proportion of the organization's 1983-84 appropriation to research as was allocated in 1982-83."

The directive has caused a stir because it breaks the traditional relationship between ministers and CSIRO in which CSIRO exercised autonomous control over the administration of its funds. The implication is that Mr Jones fears that research might suffer disproportionately as a result of the cut-backs.

The science and industry research act of 1949 establishing CSIRO, gave the relevant minister wide powers over the organization, which were subsequently curtailed by an amendment to the act in 1978 after an independent inquiry into CSIRO. This restricted ministerial direction to specific policy matters as opposed to administrative arrangements. Even so, as Dr Paul Wild, chairman of the CSIRO executive, wrote in the preface of its last annual report, "I am glad to say that no minister responsible for CSIRO has found it necessary to exercise this power of direction",

The CSIRO executive seems to be at a loss to explain $\mathrm{Mr}$ Jones' directive, maintaining that, in any case, it is the organization's policy to allocate the same proportion of funds to research from year to year. They sought clarification from $\mathrm{Mr}$ Jones, who replied that CSIRO should cut back overheads and support services, not research.

The lack of rapport between the minister and the organization may have begun at the change of government earlier this year when CSIRO's executive tried unsuccessfully to wrest the organization out of the science and technology portfolio and make it responsible to the prime minister, although the move was essentially a bid for greater autonomy. Ministerial suspicion of the organization has subsequently hardened over the issue of the Australian National Animal Health Laboratory (see Nature 303, 190 and 403), when Mr Jones sought submissions from private individuals and the bureaucracy without discussion with CSIRO. The banning of foot and mouth virus for 5 years was a blow to CSIRO which now has the unenviable task of manning the laboratory without the specific funding for 85 staff positions they requested as a separate appropriation. Furthermore, the government will be considering other recommendations of the report by the Australian Science and Technology Council which, if adopted, will make importation of other viral pathogens subject to consultations with all interested organizations. The net result would be to enmesh the importing of pathogens, some of which are already in Australian laboratories, within a bureaucratic tangle.

$\mathrm{Mr}$ Jones would like to see CSIRO expend more of its efforts on manufacturing research, particularly in the fostering of high-technology industries.

Vimala Sarma 